\title{
DISSIMILARITIES OF USING ANTITHESIS IN THE LYRICS OF TOLEPBERGEN MATMURATOV
}

\author{
Dosimbetova Abadan Aliyevna \\ Karakalpak State University named after Berdakh, \\ Nukus, \\ Uzbekistan
}

Article DOI: https://doi.org/10.36713/epra4743

\begin{abstract}
In the article, dissimilarities of using antithesis was studied in poet T.Matmuratov's lyrics. Attractiveness of antithesis can be observed through analyzing poet's some poems. Depending genre peculiarities of lyrics, it was identified that antithesis is often used effectively in poet's philosophical and publisistic lyrics. It was analyzed that antithesis is used in two forms with its composition. Dissimilarities of structures of poet's antithesis have also been studied.
\end{abstract}

KEYWORDS: Antithesis, Antithesis in one line, Antithesis in two lines, Antithesis in one repetition, Antithesis in two repetitions.

\section{INTRODUCTION}

In the half of the 20th century T. Matmuratov was one of the poets who made a great contribution to the development of Karakalpak poetry in terms of content and form. The poet took a warm place in the hearts of readers with his philosophical works which were imbued with deep lyricism. His sang about his homeland with spiritual pride. In his poetries, morality, conscience and appreciating the goodness take the main part. In this article we aim to study the peculiarities of the use of antitheses in the lyrics of $\mathrm{T}$. Matmuratov. Because we believe that the discovery of his poetic abilities through a deeper study of one of the artistic phenomena in the education of the poet complements the scientific views in this area.

\section{MAIN PART}

Among the talented people who entered the literature in the $60 \mathrm{~s}$ of the XX century, $\mathrm{T}$. Matmuratov was known in poetry for his unique way, creative style. The poet bequeathed his works such as "Aq terek pe kok terek" (1964), "Lirika" (1966), "Gozzalliq oyandi” (1970), “Aysanem” (1973), “Ashilisiw” (1977), “Arziw Shameni” (1981), "Jaqsiliq sarayi” (1986), "Juldizlar janar" (1989) to his apprentices.

Artistic studies of the poet were held and studied from the scientific point of view by the literary studies M. Nurmuhamedov, S. Akhmetov, K. Khudaybergenov, T. Mambetynizov, K. Mambetov,
S. Bahadirova, K. Orazimbetov, J. Esenov, E. Eshniyazova. However, in the porice's lyrics, the artistic function of the antithesis, the features of its use are not studied insulated. This describes the relevance of the topic chosen for our article.

One of the features of the personal style of education of $T$. Matmuratov is that it artically describes the contrast between good and evil in the world based on the lyrical feelings. The main leitmotic of the poet's education is to create an adjectivetic sense of a pedestal feelings, such as the desire for good, despair of evil, by describing the struggle of good with evil, injustice and honesty, morality. In this case, the poet is rationally use the method of describing the antithesis.

Antithesis describes the symptoms of two or more events, opposing them. In the upbringing of the poet, the method of the antithesis is rationally used to transfer contradictory phenomena into the inner spiritual world of man through a description of the external contradictory events. According to our observations, in the texts of $\mathrm{T}$. Matmuratov, the method of antithesis is used more effective than other poets. The main reason for this is a description of the meaning of life, the concepts of good and evil, injustice and honesty. Because an antithesis is a rational way to describe the contradictions.

Having studied the features of using antithesis we noticed that this method is rarely used in the philosophical and journalistic songs of the poet. 
Scientist K. Orazimbetov said: "T. Matmuratov was a poet in his own way and with his brand. The poetic skill of the poet is that he creates an artistic image that contrasts with some details and freely gives the idea that he wants to express his thoughts opposite, ". This method of contradiction, i.e. antithesis, is widely used in poethers of the poet, especially in his philosophical songs. Philosophical lyrism, revealing the meaning of life, the concept of good and evil, morality, takes a central place in poetry of the poet. The philosophical lyrism of the poet describes the views and concepts of life, the complex nature of man, morality, dignity, especially the fight of good with evil. Antithesis is used as a really effective method in the implementation of such artistic content.

Antithesis serves to reveal a clear picture of events, with internal contradictions of the object depicted. Improves the visual and aesthetic effect of the work.

Kun siwitip baslandi izgirik,

Sonday waqta sargayadi japirak,

Kim soylese kewillerdi muz qilip,

Sonday waqta baslanadi patirat,

Jaksiliktin izi menen gul oser,

Jamanliktin izi menen kim oser! [ 3,74$]$

In this song, the poet compares good and evil in his own way. Preliminary images take on a natural phenomenon, that leaves turn yellow with the onset of cold (whistle). The image then transforms the object into the spiritual world of man, and the word " cold" symbolizes the coldness of the human heart, that is, suffering. These stories are based on the complication of evil. The song uses the method of antithesis, fully reveals and emphasizes the concept of good and evil. The yellowing of the leaves, the cooling of the mood, creates a contradiction on the basis of a truly delicate, invisible inner connection between good and evil, and this resistance is evident in the last lines. Philosophical statement of the lyrical character: "Who grows in the footsteps of evil!" a rhetorical allusion that is the root of evil.

In the song "What is life?" the poet reflected the thoughts and views of the lyrical hero on life. In this song, the lyrical hero is created on the basis of a true lover of life, a demanding hero who is involved in all its phenomena, strives for goodness, honesty and does not give up in the fight against injustice. Philosophical ideas about the nature of people, the complexity of the human inner world, are skillfully introduced into the content of the song by the antithesis method.

$$
\begin{aligned}
& \text { Tiri deyin desem } \\
& \text { Jani jok onin, } \\
& \text { Oli deyin desem, } \\
& \text { Tiri kusagan, } \\
& \text { Ol da bir adam, } \\
& \text { Olmey turip olgen, }
\end{aligned}
$$

\author{
Adamlar ushin \\ Janip jurippen, \\ Shashka ak tusejak \\ Usi kuyikten. [3,96]
}

The lyrical protagonist's adornment of bad habits, unpleasant actions, his assessment of people with low mental worlds and worldviews are presented by quoting contradictory concepts in each line. The poet openly described the anger and hatred of the lyrical protagonist for low-spirited, stupid people, who have a negative impact on the development of society, especially through the antithesis "tiri deyin desem jani joq", "oli deyin desem tiri", "olmey turip olgen adamlar". The content of the poem arouses in the mind of the reader a feeling of disgust from such "living corpses".

T.Matmuratov's publicistic lyrics describe the subjective thoughts of the lyrical hero on social problems. In publicist lyricism, the antithesis is also an effective way of expressing the problems of the period, society, the contrast of the lyrical protagonist with the environment around us. In the verses like "Dunya dartlerimdi menin", "Diagnoz", "Dareje", "Geyparalardi oylap" used an antithesis to describe the lyrical protagonist's value and views on social problems. For instance:

Garri zir juwirar nege jas turip?

Tayaq torge shigar nege bas turip?

Dunyadan soraman, dunya tas qilip,

Eki kozin jumip turgan emes pe. $[4,122]$

The poem describes the feelings, inner pains and heartaches of the lyrical hero about social problems. Injustice, uncontrollability, the suffering and devaluation of kindness in society, the artistic content of unjust deeds, as well as the content of the concepts of good and evil are equally described. In particular, the "closing of the eyes of the world" to the supremacy of good over evil is an artistic depiction of the carelessness that leads to disaster in any societyAt the same time, the poet achieved an artistic result with the help of antithesis, that is, by contrasting the words "old and young man", "legs head".

T. Matmuratov divides into two in terms of the formation of antitheses in the lyrics, that is, in terms of semantic relationship: the antithesis of antonyms and the antithesis of non-antonyms.

«Contrast, in its simplest form, is an antonym, but in other words, a form of artistic attitude that opens a wide way to the expressive content of the poem and conveys a high ideological meaning» $[5,231]$.

Literary critic T. Boboev theoretically substantiated the artistic function of antitheses and the importance of antonyms, saying: "Antonyms, contrast pictures, contrasting images and situations form the basis of antithesis. The reason is that the contradictory phenomena are contrasted and 
compared with each other, the description of the contrast allows to understand the specificity, in the process of comparison it is possible to reveal the object of the description in depth and concrete ". [6, 450].

The function of antonyms of antithesis can be seen in many poems of the poet. In the poems of the poet the antonyms "low-high" are often used in artistic service.

Sen shikkan biyikke shig`a almaspan,

Jurtka khamirim jurmes, birak umitpa,

Paste dep kulme sen, men khadal bolsam,

Biyik bola alrman paste turip ta. $[3,42]$

These lines from the poem "The nature of the poet" describe the human appearance, character and position of the lyrical hero in the image of the poet. In this poem, too, the antithesis is used to show the art of content. At the same time, the lyrical protagonist's views on honesty and humanity are presented through antithesis. In the above example, with the help of the antonyms "high-low", the human height and low are contrasted, and the meaning of height is explained in depth. Depending on the value of the lyrical hero to the heights and lows, the characteristics of his character are revealed.

Contrasting development of thought in the poems of the poet also makes antitheses with "bittersweet" antonyms. While it is used in many poems to convey the joys of life, in the poem below it describes a mother's love for her child.

Ana degen jariklik,

Perzentine berib barlik dushshini,

Kalsadagi miyi awitkip,

Ozi alip kalar ashshini,

Sonliktan da onin atasi,

"Palegi ashshi" dep kabak uyedi. [3,73]

The poet uses the popular proverb "stem bitter, fruit - sweet" as a motive to express his ideas and opinions, on the basis of which he uses the antithesis of the greatness of the mother and the infinity of her love on the basis of new poetic thinking.

When using the method of antithesis, not only antonyms are used, but also non-antonyms, that is, words that have opposite meanings in the context. In T.Matmuratov's lyrics we often find such a way of making an antithesis. For instance:

Meyli,dalalarda salkim izildi,

Bolsa da terekler japiragi sargish,

Miywaga malingan altin guzimdi,

Almastirgim kelmes bakharge khargiz,

Jaslik, meni shakirmay sen, koya tur,

Omirimnin altin guzi kiyatir. [7,82]

The poet's poem, which begins with the words "Kokerek khallaslamas burungyday", gives an assessment of the life of the lyrical hero of middle age. The youth and post-youth period of the lyrical protagonist's life are artistically described by the antithesis method. In this case, the words "spring and autumn", "youth and golden autumn" are antonyms. The words "spring" and "autumn" are metaphorized, describe the periods of life depending on a person's age and contrast with each other. However, in the last lines, the epithet metaphor "golden autumn" in the opposite sense to the word "youth" is used. In the poem, through context antonyms, the lyrical hero's feelings of love for life in any period are expressed. In the poem "Gul gul donip tursin ana tabiyat" beautiful feelings in the spiritual world of the hero are described by the scenes of nature. The following antitheses were used in these scenes: "I saw a flower grow on a hard rock." At the same time, sencetiveness and endurance, which are inherent in human nature, are contrasted through natural objects. This contradiction is conveyed by the metaphorical words "flower" and "hard stone".

The antithesis can be used to draw an emotional image by contrasting the object or event that is the focus of the poet's attention with the object or event that is opposite to it.

The structural specificity of the antithesis in the lyrics of T. Matmuratov is of interest to students. In this case, it is possible to come across antitheses given in one line, two lines and one strophe, or two strophes. In our opinion, each of them has its own peculiarities in application. The antitheses in a row represent a repetitive image, and the antitheses in two rows represent the object of the image as opposite. The antitheses along one or two paragraphs compare either the subject or the event in contrast.

\section{ANTITHESIS IN ONE LINE}

Opposing words (also antonyms) which form antithesis also come in one line in poet's poems. For example, let's pay attention to the following lines from his poem called "Words to my friends": Sometimes I cry, sometimes I might laugh,

this. $[9,42]$

Human was brought into being like

These lines mean lyric character's fate, his thoughts and viewpoint about life and also we can understand that people's lives consist of obstacles such as happiness and sadness, troubles and joy. In this line "Sometimes I cry, sometimes I might laugh", antithesis description was used in one line to give the moral state of the lyric character.

Life is sometimes kind, but evil at times

This line from his poem called "Life can speak" fulfilled the role of antonym. Here, philosophical opinion about life was depicted acceptably with the help of antonyms "kind and evil". The poet was able to express depicting object with inner opposition by means of antithesis used in one line. 


\section{ANTITHESIS IN TWO LINES}

In poet's lyrics, antitheses like this are expressed through putting against the two features of depicting object.

People should love flowers,

Also its thorns should be loved.

Here, two features of depicting object (flower and its thorn) were put against to express lyric character's precious feelings to his dwelling place. In this way, nature of depicting object is represented by means of antithesis. The main point is portrayed by the eagerness of lyric character to his dwelling place, being ready to any duty of his motherland and loving it with its all nature and peculiarities. So, it is implied that dwelling place is also attractive with its all difficulties and troubles.

\section{ANTITHESIS IN ONE REPETITION.}

In poet's lyrics, the way of portraying with antithesis can be found in linked one repetition form. In most cases, the thought which comes in the first two lines is put against to the last two lines.

Nothing is cold except words,

People feel cold with one word,

Nothing is hot except words,

People melt with one word. $[7,10]$

The meaning of the first two lines was put in contrast to the meaning of the last two lines on expressing the point of people's inner nature and their unclear, complex behavior. It is possible to make someone cold or melt with the influence of words. In the poem, life truth like this is expressed with antithesis. The thought in the first two lines were given in contrast to the thought of the last two lines.

\section{ANTITHESIS IN TWO REPETITIONS}

In this case, we think that two incidents, two events are put against to each other and compared. Based on this, the inner peculiarity of depicting object is deeply expressed. For instance, two different souls are compared with each other in poet's poem called "Soul":

There's a soul: you feel hardly anything,

Sensing coldness like winter,

As if forever ice like North Ocean,

Saw I it felt cold in both winter and summer.

There's a soul: there grows charming flowers,

Poetry is better than it,

It is the river of great humanity,

Saw I it flows with high waves.[7,70]

In these lines, two different depicting objects are portrayed with their inner differences and specific peculiarities and developed in opposite direction to each other. In the first repetition, it was depicted that a person who is careless to life beauty and shows unfriendly attitude towards people around, while in the second repetition, we can perceive that a person who feels beauty of life incidents and enjoy them, kind to other people around him. Lyric character's thoughts and feelings are portrayed about people like these. The poet puts in contrast these two repetitions on revealing life truth in large scales like this using antithesis.

\section{CONCLUSION}

Generally, there are some dissimilarities of using antithesis in T.Matmuratov's lyrics and it depends on his specific skills on creativity. Antithesis is often used widely as an effective method on representing good meaning in his philosophical and publicistic poems. In poet's lyrics, antithesis formed with antonym words as well as not antonyms provides the attractiveness of the main point. Antithesis in poet's lyrics is also different in their structures and serves to express the meaning of poem attractively.

\section{REFERENCES}

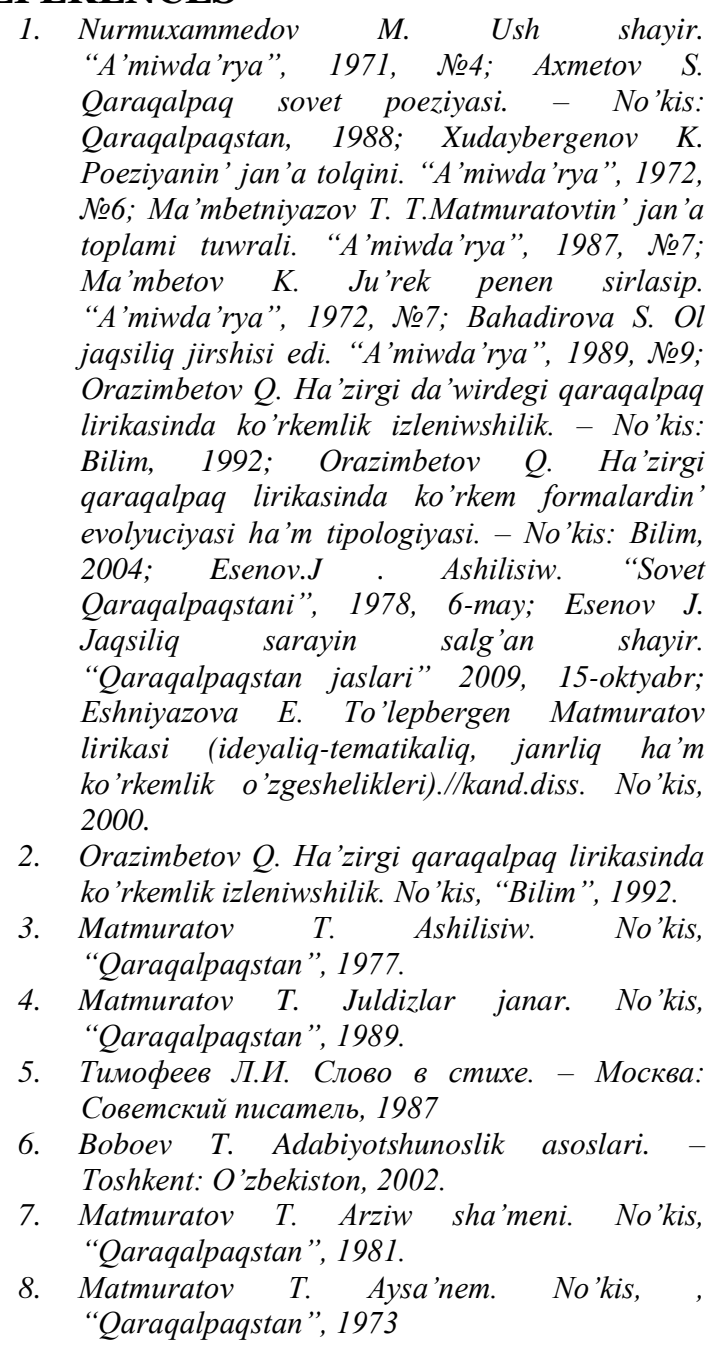

